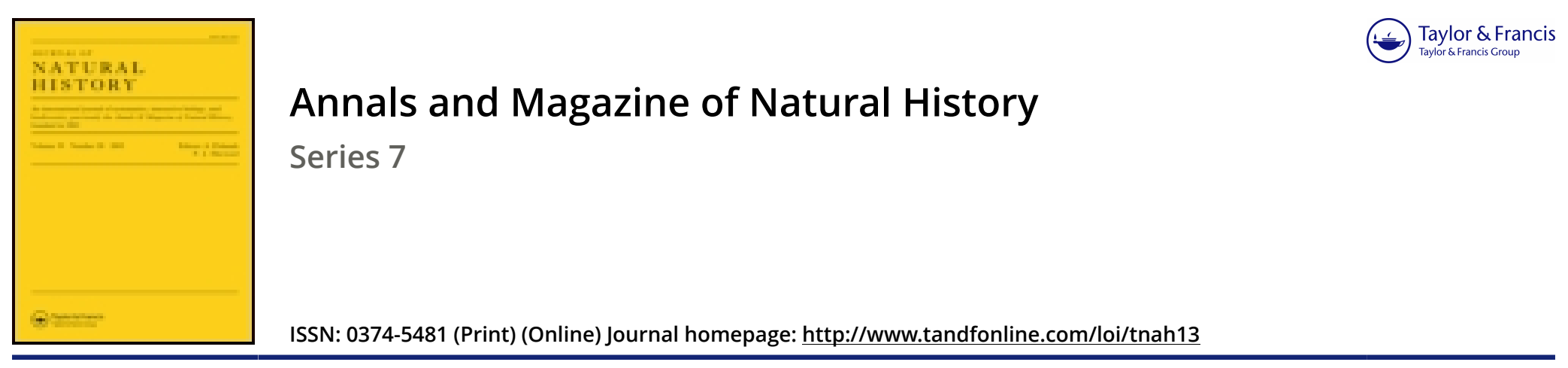

\title{
XXVI.-Description of a new fruit-bat from New Guinea
}

\section{Oldfield Thomas}

To cite this article: Oldfield Thomas (1900) XXVI._Description of a new fruit-bat from New Guinea, Annals and Magazine of Natural History, 5:26, 216-217, DOI: $10.1080 / 00222930008678270$

To link to this article: http://dx.doi.org/10.1080/00222930008678270

册 Published online: 22 Sep 2009.

Submit your article to this journal $\sqsubset \pi$

Џ Article views: 3

Q View related articles $\sqsubset$

Citing articles: 1 View citing articles $\square$ 
some of the smaller forms, such as $P$. phceomelas, Günth., and others, but is readily distinguished from any of them by its splendid rufous colour.

This species is one of the handsomest of the mammals that I have been fortunate enough to discover in Sarawak, and I have ventured to apply to it the name of my friend Mr. Oldfield 'l'homas, of the British Muscum, to whose help and encomragement $I$ owe much of the success that has attended my work on the mammals of Borneo.

\section{XXVI--Description of a new Fruit-Bat from New Guinea. By OldFiend 'Thomas.}

\section{Cephalotes aello, sp. n.}

Most nearly allied to C. major, Dobs., but larger and much more prominently striped dorsally.

Form, judging from skin and shape of skull, stout and heavy. Fur straighter, crisper, and less woolly than in C. major. General colour above brownish buff, more buffy on the head, browner on the shoulders, becoming yellow on the loins; dorsal stripe very broad and prominent, blackish brown, commencing on the occiput and running right through on to the interfemoral membrane, more than half an inch broad in the centre of the back, where it prominently contrasts with the yellow on each side of it. Fur along flanks above also brown, edging the yellow externally. Cheeks and chin grey. Uncier surface deep reddish, the middle line of the chest yellower.

Ears apparently rather larger and more pointed than in C. incjor. Distribution of fur much as in that species. Interfemoral membrane comparatively broau, about 15 millim. deep in the centre; on'y surpassed by the tail by about 2 millim., but the latter is perhaps imperfect, although its end looks nuch as in the other species, where it surpasses the nicmbrane by 10 millim, or more.

Skull broader, heavier, and with mure widely expanded aygomata than in $C$. major. Orbits very large, their greatest transverse diameter nearly 12 millim., as against 9 millim. in C. major. 'T'eeth broad and heavy, worn down in the type, but their cusps apparently as in $\dot{C}$. major.

Dimensions of the type (in skin):--

Forearm 86 millim.

Head and body (stretched) 120 ; tail 22 ; ear (dry) 17 ; thumb, without claw, 30 ; fifth finger 110 . 
Skull : greatest breadth 26.5 ; tip of nasals to angle behind postorbital processes 18.8 ; least interorbital breadth $7 \cdot 2$; palate length from gnathion 19.5 ; width outside last molars $12 \cdot 2$; front of canine to back of last molar $11 \cdot 3$.

Hab. Milne Bay, S.E. New Guinea.

Type B.M. no. 99. 12.3.1. Collected 5th April, 1899, by Mr. A. S. Meek.

This fine species may be readily distinguished from its ally C. major by its larger size, striking coloration, and (if that organ is perfect) shorter tail. Like that species, it too doubt belongs to the subgenus "Bdelygma," separated by Dr. Matschie from the typical Cephalotes; but I confess I can see no sufficient reason for subdividing the genus. The second lower premolar in some specimens of $C$. cephalotes has the second cusp said by Dr. Matschie to be characteristic of Bdelygma.

It may also be noted that of specimens referred to C.cephalotes those from Celebes, Amboina, and Timor Laut have markedly larger skulls and longer forearms than those of the rest of the Papuan subregion. The smaller form should apparently be distinguished under the name of $C$. albiventer, Gray. Of this latter the Museum possesses examples from Morty Island (type), Admiralty Islands, Key Islands, British New Guinea, and Cape York. Whether its range overlaps that of the larger $C$. cephalotes remains to be proved.

With the Cephalotes Mr. Meek has sent home a number of specimens of Pipistrellus papuanus, Pet, and these prove that the species is subject to the peculiar form of erythrism already described in several other bats, some of the specimens being bright rufous, while others are dark brown.

Another species discovered by the same collector, Emballonura Meeki, 'Thos., found by him in the Trobriand Islands, has recently turned up in a somewhat distant locality, namely in the Key Islands, where it occurs in the same collection as the remarkable Rhinolophus achilles described in the last number of the 'Annals.'

\section{XXVII.-Descriptions of new Neotropical Mammals.} By Oldfield Thomas.

\section{Conepatus zorilla, sp. n.}

Size medium, about as in C. clilensis, smaller than in C. quitensis. Fur comparatively very short, fine, glossy, almost without underfur, quite different to the long, corrse, 